\title{
Ingmar Bergman, the Multimedial Author
}

\author{
Kristína Tóthová
}

Ingmar Bergman and His Legacy. 23-25 October 2018, The Cabinet of Audiovisual Dramatic Arts, Lumière Cinema, Bratislava, Slovakia.

The fifth interdisciplinary seminar titled Ingmar Bergman and His Legacy (developed from the initiative of a non-profit organization The Cabinet of Audiovisual Dramatic Arts (KADU) and the Film and Television Faculty of the Academy of Performing Arts (FTF VŠMU)) took place over three intensive days at the Lumière Cinema in the city centre of Bratislava. The project was supported by the Slovak Film Institute, Film Europe and other partners, and taken under the patronage of the vice-dean of FTF VŠMU, professor Zuzana Gindl-Tatárová.

The seminar featured lectures presenting Bergman's artistic work from many different perspectives and was accompanied by screenings of his films and one recording of a theatre production. The selected movies presented Bergman's various creative periods, from his early beginnings in Wild Strawberries and The Seventh Seal (both filmed in 1957), through Persona (1966), to Fanny and Alexander (1982).

Organizers of the seminar chose to begin with one of Bergman's later movies - the screening of the 188-minute-long movie version of Fanny and Alexander with the foreword of Gindl-Tatárová. It was a pity that they did not opt for the original four-part television series (312 minutes) as it would be a unique chance to introduce this not so well-known version to Slovak audiences. The shorter version was made for cinemas, so the version for television offers a more developed storyline and explains the actions of some characters in depth. However, it is only understandable that the integration of such a long piece would be a very difficult task for the organisers. It might have, nevertheless, been contributive regarding the following panel discussion about Slovak and Czech theatre adaptations of Bergman's works - one of the guests was the Slovak theatre director Marián Amsler, who directed the production of Fanny and Alexander, where he used the television version as well as the film story.

Three theatrical adaptations were presented in a discussion chaired by the theatrologist Soňa Jánošová: the Czech production After the Rehearsal (2011) by Theatre in Reznická directed by Martin Huba, the Slovak monodrama Persona (2016) under Tomáš Procházka's direction in Aréna Theatre, and the previously mentioned Marián Amsler's stage adaptation of Fanny and Alexander (2016) made for the Slovak National Theatre. Both directors of the younger generation used film elements in their productions: in Fanny and Alexander, the principle of live cinema was employed, as the live stream from cameras was projected on the screens on the stage, and the production of Persona contained video art.

The discussion was opened by the Slovak translator of Bergman's literary work 
Milan Žitný, who presented the history of Slovak translations with focus on their lexical and content form. He described Bergman's frequent usage of religious motifs and ecclesiastical terminology in his texts. Bergman quite often quoted sermons and the prayers of his father Erik Bergman, Swedish pastor and parish minister of the Lutheran Church, which is the reason why the process of translation presents such a complicated task.

The evening was dedicated to the screening of Wild Strawberries (1957), but it was also the official opening of 'the seminary festival'. It was opened by the director of the Ingmar Bergman Foundation, Jan Holmberg, who noted that the non-Scandinavian audience members may understand Bergman's poetics slightly better than the Scandinavian ones because they are not so sated with his work and that is why they can look for different interpretations in his movies.

On the second day, after the press conference with Jan Holmberg, a recording of Bergman's adaptation of Shakespeare's The Winter's Tale (1994) from the Royal Dramatic Theatre in Stockholm was screened. Bergman conceived this more than three-hour-long production as an inner conflict of King Leontes and the darkness of his soul. Doubts increased the ruler's cruelty, and he became a tyrant. Here, the religious theme was represented by the symbol of the crucified Jesus and his resurrection. The King-flagellant eventually wins the forgiveness of his loved ones, mainly his wife Hermione, who is here likened to the Mother Mary. The crudeness and grievousness of the first half of the production were balanced with the comic scenes featuring the character of Autolycus. As one of the organisers Adam
Hrapko mentioned in the introduction to the movie before the screening, Bergman significantly altered the original metric structure, ordering a new prose retelling of the play, which was translated into Swedish specifically for this production. The whole production is characterized by a gloomy mood, despite the director's tendency to lighten the atmosphere with humorous scenes. Bergman was getting through a difficult period of his life, with his wife struggling with severe illness and dying one year later.

Unfortunately, there was no lecture focusing on Bergman as a theater director, despite him being quite famous (not only) in his country and dedicating his whole life to the theatre. It would also be enriching to get to know more about Bergman as an author, especially when considering the fact (repeated throughout the conference) that Ingmar Bergman is the most frequently staged Swedish playwright).

In his masterclass 'Ingmar Bergman at 100 and Beyond', Jan Holmberg concentrated on the author's film directions. On particular examples from Bergman's movies (i.e. The Seventh Seal, Cries and Whispers, Persona, Winter Light), he demonstrated the main motifs Bergman used. There were many religious references as well as quotations and passages from the Bible. Holmberg also paid attention to Bergman's usage of anaphors in the movies.

The screening of Ingmar Bergman through the Choreographer's Eye showed the Bergman-phenomenon through the art of dance. Four contemporary Swedish choreographers - Alexander Ekman, Pär Isberg, Pontus Lidberg, and Joakim Stephenson made short dance pieces that were inspired by Bergman's movies Persona and Saraband, but also by the Swedish island 
Fårö, where the movie was shot. Ingmar Bergman Jr. participated at the production of the movie.

The philosophical point of view of Bergman's work was emphasized by the essayist Július Vančovič, author of the anthropological and existential reflection entitled Behind The Scenes of Life. The Existentials of Ingmar Bergman, Essays. His paper analysed the political and spiritual crisis of the 20th century human in comparison with the answer of 'the Dostoyevsky of the Film'.

The screening of The Seventh Seal fittingly followed this searching for a new spirituality in our lives.

The lecture of a duo of psychiatrists Jozef Hašto and Peter Breier focused on the importance of the expression through art in the artist's life, which might be perceived as a form of psychotherapy. Before the debate, Bergman's last interview with the Swedish journalist Marie Nyreröd, 'Bergman and Fårö '(2004), was screened, in which he described his fight with his inner demons. The claims of the psychiatrists in their lecture were based on the information found in Bergman's biographies. The authors pointed out the thematical division of Bergman's work into three phases. Faith in God, demonstrated in The Seventh Seal, characterized the first phase. Next, Bergman needed to solve his relationship with his parents. In the movie Persona, he deals with the relation to his mother, in Fanny and Alexander with his father. The relevance of the books written by Bergman is questionable, among others because of his good storytelling qualities. It would be interesting to get acquainted with research of foreign researchers, who have access to the materials in the Swedish archives.

The following screening of Persona let Bergman speak for himself.

The ending of the seminar belonged to the stage production Summer with Monika, produced by the group of students of the Academy of Performing Arts in Prague called Drama 16:20. It offered the audience a possibility to experience the transition from film into the theatre within one hour. The adaptation of the film script from 1953 thematically coincides with the group's ideas, and the love story of a young couple can still be seen as topically interesting for the contemporary audience. The third day of the seminar, already full of existential questions, ended up with a query about the current social crisis, about young people searching for their own identity. The production directed by Aminata Keita posed thought-provoking questions about one's identity and the course of not only our lives, but also the society in which we are living.

The organizers also prepared a reward for diligent attendees in the form of a short summarizing lecture on Bergman's biography, written by the Swedish expert on Bergman Maaret Koskinen. The seminar significantly contributed to the knowledge about the complexity of Bergman's oeuvre, although the programme structure might have been more coherent with more analytical presentations. Despite this criticism, the ambition to organize this type of event in the Slovak context should be appreciated. 